\title{
Is It Easier for Minority Groups to Integrate in the Work Force when they are Self-Employed? A Case Study in the Israeli Labor Market
}

\section{Tal Shahor}

\author{
The Academic College of Emek Yezreel, Israel
} tals@yvc.ac.il

\section{Doi:10.5901/ajis.2015.v4n1s2p277}

\begin{abstract}
One of the main problems facing many countries today is the integration of minorities in the labor market. This problem applies in countries with a high immigrant intake and also in countries where the minorities are indigenous. Israel has a Jewish majority which manages the economy and an Arab minority which should be integrated in the labor market. One question that arises in this case study is whether the minority sector is better able to become integrated in the labor market as wage earners or as self-employed. The goal of this study is to examine this question in the context of the Israeli economy by comparing between the Arab sector and the Jewish sector. The first stage of the study compared the income of the self-employed compared to the income of wage-earners in each population group. The results at this stage showed that in the majority group, the income level of the wage-earners and the self-employed is almost the same, whereas in the minority group the income level of the selfemployed is much higher than the wage-earners (a gap of 33\% in favor of the self-employed). The second stage of the study examined the effect of the level of education on the decision to be self-employed in each of the population groups. To this end, we checked the self-employment rate for each level of education. The results showed that in the minority group (Arab sector) the level of education of the self-employed is higher than that of the wage-earners, whereas in the majority group (Jewish sector) the level of education of the self-employed is lower.
\end{abstract}

Keywords: self-employed; labor market; minorities; Israel.

\section{Introduction}

In recent years, many countries have found it necessary to address the question of how to integrate minority groups into the labor market. This question is relevant in countries that have a constant intake of immigrants and also in countries with an Indigenous minority. To successfully integrate minority groups into the labor market, we must first check if the pattern of employment of the minority group differs from that of the majority. This study compares between the selfemployed and the wage-earners in each of the population groups. The research question for the purpose of this article is whether there are differences between the minority group and the majority group in three specific areas: the rate of selfemployed in the work force, the income level of the self-employed compared to the income level of the wage-earners, and the level of education of the self-employed compared to the level of education of the wage-earners.

Numerous studies have examined the subject of wage-earning workers and the self employed throughout the world. David \& Blanchflower (2004) carried out a study that was based on surveys performed in a number of OECD countries. In that study, the first section examined each of the countries separately, and the second section examined all the countries together in a group context. The results of this study showed that gender was one of the factors that affected the self-employment rate. More men are self-employed, although between the years 1994 to 2002, the gap between the number of self-employed men and self-employed women decreased. Age is another factor that affects the rate of self-employment. The rate of self-employed increased relative to the increasing age of participants in the study but only up to a certain level (up to age 54 in 1994 and up to age 61 in 2002), after which the number of self-employed began to decrease. The effect of education on the self-employment rate is less clear. In most countries in Europe increased education is linked to a decrease in the self-employment rate. However in the USA, the opposite occurs - the selfemployment rate increases together with the increased level of education. The same result was received when the data was examined using a continuous variable of age, and also when the data was examined using dummy variables for various age groups. The outcome is also not uniform for the question of self-employment rates in ethnic minorities. In some countries in Europe, the self-employment rate among ethnic minorities is higher than in the general population. However, in the USA there is less self-employment among Afro-Americans and Hispanics, apparently because of a lack of initial financial liquidity. In other countries a lack of financial liquidity may also be the factor that prevents people from 
becoming self-employed. Many wage-earning employees report that they would prefer to be self-employed. The question to be asked was why they did not become self-employed. There are those who maintain that people do not report what is actually good for them. But the findings indicate that the self-employed are more satisfied with their work. Therefore the question that still remains unanswered is why so few wage-earning employees become self-employed.

\section{International Comparison}

According to Blanchflower (2004), a comparison of self-employment rates between countries or between periods, necessitates differentiating between self-employed farmers and the self-employed in other areas because during recent decades, the number of self-employed farmers has decreased in the majority of countries. Furthermore, usually, in those countries that are more developed, the methods of cultivation have improved thereby requiring a smaller number of farmers. This process does not stem from social or economic reasons which we seek to examine but rather from technological developments in agricultural cultivation. And if we check the self-employment rate including farmers, we will find that in the majority of countries there has been a decrease in self-employment over the years. If we consider those who are self-employed but are not farmers, in some countries we can actually see an increase in the numbers.

An interesting question to ask is "Does having a large number of self-employed (in this case the majority of whom will be small business owners) benefit the economy?" Many countries support "small" independent businesses based on the thinking that this is the way to promote economic development particularly in the weaker layers of society. According to this approach, small businesses can create jobs with a smaller investment. However, the study by Davis, Haltiwanger and Schuh (1996, p. 57) claims that while small businesses do indeed generate many new job opportunities they also cause the loss of many old jobs because the average lifetime of small businesses is shorter. It is therefore unclear whether the existence of numerous small businesses at the expense of large businesses does actually increase the rate of employment. However it is clear that the larger businesses do actually create more stable jobs. An article by Wagner (2004) which examined the subject of entrepreneurship ${ }^{1}$ found that the better the financial state of the families the more likely they were to become entrepreneurs. Examination of the effect of education on entrepreneurship revealed that low and high levels of education reduced entrepreneurship; in other words, the highest level of entrepreneurship can be found in the population with an average level of education. The study led by Wagner also compared the rate of entrepreneurship in different countries. The study examined, among other aspects, the correlation between the rate of entrepreneurship and the GNP, and found that a U-shaped ${ }^{2}$ correlation linked the two parameters. The implication of this correlation is that in poor countries the rate of entrepreneurship is high apparently because work opportunities for wage earners are limited. Consequently, an increase in the GNP (and an increase in employment opportunities) reduces the number of entrepreneurs. However, at a certain GNP level the rate of entrepreneurs once again increases, seemingly because in these countries the funds required to establish a business are more readily available.

Gindling and Newhouse (2014) studied the subject of wage-earners and the self-employed in developing countries. In these countries the main problem is how to extract the poor farmers from the cycle of poverty. According to this study, this goal can be achieved in two stages. In the first stage, the farmers need to be helped to become independent in non-agricultural areas, and only in the second stage do they need to be helped to become wage-earners. The significance of this finding is that being self-employed can be a stage in the progression of economically weak groups on the way to becoming integrated into the workplace. Andersson and Wadensjö (2003) found that in Sweden and Denmark, the rate of self-employment among immigrants is much higher than in the rest of the population. Additionally, they found that the income of self-employed immigrants is lower than that of wage-earning immigrants. They reached the conclusion that immigrants who chose to be self-employed did so because they were experiencing difficulties finding employment as wage earners in jobs with a reasonable pay rate. The study by Zulema (2013) which examines the rate of self-employment among immigrants in the USA paints a different picture. According to this study, the rate of selfemployment among new immigrants is lower than the rate of self-employment in the general population, but this rate grows over time. Zulema maintains that over time the changes in the rate of self-employment among immigrants may indicate the level of their integration in American society at least in terms of their economic status. The study refers to three integration options:

\footnotetext{
1 The study by Wagner looks at entrepreneurs, in other words, people who set up new businesses. It does not deal with the number of self-employed who are already operating.

2 Similar results were found in an article by van Stel et al. (2003)
} 
1. Independence as a process of integration in the mainstream: the immigrant undergoes a final stage of joining the mainstream of the society in a process that is consistent and final. In the area of independence, this process is one in which the rate of self-employed converges with the accepted rate in the general population. In this process there should not be any difference between men and women.

2. Independence as a process of downward integration: the number of self-employed remains lower than in the rest of the population. The lack of integration is more extreme among the men and consequently the rate of self-employment will be even lower.

3. Independence as a hindrance to integration: the immigrants have traits that are suitable for becoming entrepreneurs and self-employed (immigrants that come to the USA from Korea are a case in point). Consequently the rate of independence among them is greater and perhaps even grows over time. This process delays integration because they are less integrated in the work place, and focus on their own occupational areas.

Other studies drew different conclusions. George (1986) found that in the 1970s and 1980s the rate of selfemployment among immigrants in the USA was higher. Shahor (2014) found that in Israel the rate of self-employment in the minority sectors was higher. However, it is possible that also in Israel the convergence of the rate of self-employed minorities with the rate of self-employed in the main social sector (in other words, the Jewish sector) could indicate economic integration. There is another interesting finding in the study done by Zulema (2013) which indicates that the influence of age on the self-employment rate has an inverse $U$ shape; in other words, the rate of self-employment is lower among the young and the elderly, and is higher among the middle-aged generation.

This study focuses on Israeli citizens living inside the Green Line (Israel's border until 1967 as determined by the United Nations). The majority of citizens within these borders are Jewish (80\%), and there is a large minority of Arabs (the remaining 20\%). Within the population of Arabs who are Israeli citizens (and are therefore included in the this study), the vast majority are Muslims; approximately $10 \%$ of the Arab population are Christians, which in many ways (birth rate, level of education, etc. ) differentiates them from the Muslim group. In socio-economic terms, the state of the Arab minority is inferior. One of the components contributing to the low socio-economic status that is addressed in this study is the inferior state of Arab sector employment, and in particular the wages earned for work performed. Epstein, Gharrah and Cohen (2001), Hasson Abu Assabah (2004), Hasson and Kariyeini (2006) found employment inequality which has its origins in the lack of employment options in the Arab settlements, and the difficulties encountered by Arabs when they attempt to become part of the workforce in Jewish settlements. Additionally it was found that despite the improved education of the Arab workforce, they are unable to realize their full potential in the Israeli work force. Friedman and Zussman (2008) found that between the years 1987 to 2005, the difference in the hourly rate of pay paid to Jews and Arabs had actually increased. There are a number of approaches that could explain the differences in the rates of pay received by the different employee groups:

1. Human Capital approach - this approach, presented by Becker (1993), claims that an employer operating in a competitive market who aims to increase the profits as much as possible, will pay the employee according to their marginal output. This approach maintains that if an employee with human capital produces more than an employee without human capital, the employee with the human capital should be earning a higher wage.

2. Sex Segregation approach (Haberfield 1990) - this approach focuses on the characteristics and attributes of the labor market (whereas the Human Capital approach focuses on the employee and their attributes). In this approach, the wage is paid according to profession and not according to employee. Some professions are more important to the employer than other professions and positions. According to this approach, Jews will earn more than Arabs if the jobs that they are performing are among those for which the employer pays a higher rate.

3. Another possibility is that of discrimination against one of the sectors in the population (in this case, against Arabs): According to the human capital approach, discrimination occurs when the average wage of the Arabs is lower than that of the Jewish population even though the average human capital of the Arabs is similar to that of the Jews. According to the sex segregation approach, there is evidence of discrimination when lower wages are paid for professions performed by Arabs.

In all three cases, the end result is that Arabs find it difficult to become integrated into the Israeli workplace as wage-earning employees. One way to circumvent this difficulty is to join the self-employed sector, where the person does not have to "show their papers", and their income is determined by their ability to meet the needs of their customers. It can therefore be assumed that the rate of self-employment in the Arab sector will be greater, and that the disparity in wages earned between Jews and Arabs in the self-employed sector will be smaller than the disparity in the wage-earning 
sector.

\section{Empirical Study}

The data for this study were taken from the income survey for 2011 (the most recent survey available at the time of writing of this article). The first stage involved examining the average traits of the various population groups, divided according to status in the workplace (wage-earners or self-employed), ethnic group (Arabs or Jews), and gender (male and female). Table 30 below lists the rate of self-employment among all the workers in each of the different groups.

Table 30: Self-Employment Rate among All Workers in Each Population Group

\begin{tabular}{||c||c|c||c||}
\hline & Arabs & Jews & Arab to Jewish Ratio \\
\hline \hline Men & 0.145 & 0.156 & 0.931 \\
\hline Women & 0.061 & 0.079 & 0.779 \\
\hline Total & 0.121 & 0.117 & 1.04 \\
\hline
\end{tabular}

As can be seen in Table 30, among the men there is very little difference between the Arabs and the Jews. Among the women, the difference the Arabs and Jews is greater. However, it is important to note that the data in this table show the self-employment rate for all workers. The number of working women is small 3 therefore the data for this group is likely to be problematic. Table 31 below shows the income of the self-employed in relation to the income of wage-earners according to the same groups.

Table 31: Self-Employment Rate among All Workers in Each Population Group

\begin{tabular}{|l||c|c|c||}
\hline & Arabs & Jews & Arab to Jewish Ratio \\
\hline \hline Self-employed Income (Men) & 7,884 & 11,540 & 0.683 \\
\hline Wage-earner Income (Men) & 5,948 & 11,146 & 0.534 \\
\hline Self-employed to Wage-earner Ratio & 1.33 & 1.04 & \\
\hline \hline Self-employed Income (Women) & 4,748 & 7,318 & 0.649 \\
\hline Wage-earner Income (Women) & 4,734 & 6,858 & 0.683 \\
\hline Self-employed to Wage-earner Ratio & 1.01 & 1.07 & \\
\hline
\end{tabular}

The interesting point in Table 31 is the fact that the income earned by self-employed Arab men is much higher (33\%) than the income earned by wage-earning Arab men. This result could indicate that it is difficult for male Arab workers to become integrated as wage-earners in the Israeli labor market, and therefore are more successful as self-employed. Table 32 below shows the number of years of education for each group.

Table 32: Years of Education

\begin{tabular}{||l||c|c||}
\hline & Arabs & Jews \\
\hline \hline Years of Education Self-employed (Men) & 11.76 & 13.93 \\
\hline Years of Education Wage-earner (Men) & 11.64 & 14.18 \\
\hline Ratio of Self-employed to Wage-earners & 1.01 & 0.98 \\
\hline \hline Years of Education Self-employed (Women) & 11.46 & 15.07 \\
\hline Years of Education Wage-earner (Women) & 13.29 & 14.17 \\
\hline Self-employed to Wage-earner Ratio & 0.86 & 1.06 \\
\hline
\end{tabular}

The interesting conclusion to draw from Table 32 is the fact that among the men, there is no significant difference in the level of education between the wage-earners and the self-employed. This is noticeable in light of the fact that the income

${ }^{3}$ The sample for this survey includes 37 self-employed Arab women compared to 220 self-employed Arab men, 1302 self-employed Jewish men, and 679 self-employed Jewish women. 
earned by the self-employed Arab is significantly higher than the income of the Arab wage-earners. The fact that there is no difference in the level of education raises the possibility that the Arab men are not managing to utilize their level of education in the general labor market, and consequently are succeeding more as self-employed. The only group showing a significant difference between years of education of the self-employed and years of education of the wage-earners is the group of Arab women where the level of education of the self-employed women is the lowest of all the groups. In the men's group, we can see that the level of education of the Jewish men is the highest (which could be the reason for the difference in income); however, the disparity between self-employed and wage-earning men in both groups (Arab and Jewish) is negligible. As mentioned previously, the number of self-employed Arab women in the sample is very small, thereby making it difficult to reach conclusions regarding this group. For this reason, from this point forward, the study will focus only on the men.

Another way to check the level of education is by reviewing the diplomas that the workers received from the last educational institute in which they studied. (See Table 33 below)

Table 33: Data (in \%) for Diplomas Received from Last Educational Institute

\begin{tabular}{|c|c|c|c|c|c|c|c|}
\hline \multirow[b]{2}{*}{$\begin{array}{l}\text { Level of } \\
\text { Education }\end{array}$} & \multirow[b]{2}{*}{ Type of Diploma } & \multicolumn{3}{|c|}{ Arabs } & \multicolumn{3}{|c|}{ Jews } \\
\hline & & \begin{tabular}{|c|} 
Self- \\
Employed
\end{tabular} & $\begin{array}{l}\text { Wage- } \\
\text { Earner }\end{array}$ & $\begin{array}{l}\text { Self-employed to } \\
\text { Wage-earner Ratio }\end{array}$ & $\begin{array}{c}\text { Self- } \\
\text { Employed }\end{array}$ & $\begin{array}{l}\text { Wage- } \\
\text { Earner }\end{array}$ & $\begin{array}{l}\text { Self-employed to } \\
\text { Wage-earner Ratio }\end{array}$ \\
\hline \multirow{3}{*}{ Low } & Elementary & $31 \%$ & $35 \%$ & 0.91 & $13 \%$ & $9 \%$ & 1.54 \\
\hline & High School & $21 \%$ & $24 \%$ & 0.91 & $26 \%$ & $20 \%$ & 1. 31 \\
\hline & Matriculation & $16 \%$ & $20 \%$ & 0.83 & $13 \%$ & $20 \%$ & 0.65 \\
\hline Middle & $\begin{array}{c}\text { Non-Academic } \\
\text { Tertiary }\end{array}$ & $13 \%$ & $6 \%$ & 2. 13 & $16 \%$ & $17 \%$ & 0.94 \\
\hline \multirow{2}{*}{ High } & BA & $11 \%$ & $11 \%$ & 1.00 & $19 \%$ & $19 \%$ & 1.01 \\
\hline & $\mathrm{MA}+\mathrm{PhD}$ & $3 \%$ & $3 \%$ & 0.98 & $11 \%$ & $14 \%$ & 0.80 \\
\hline
\end{tabular}

As can be seen above, in the Arab sector the rate of self-employed males with low education is lower than the rate of wage-earners with the same level of education. In the Jewish sector the situation is reversed - in the Jewish sector, the rate of self-employed males with a low level of education is higher than the rate of wage-earners with the same level of education. If we look at those with a middle level of education (non-academic tertiary education), we will see that the situation is switched around. In the Arab sector, the rate of self-employed males with non-academic tertiary education is much higher than the rate of wage-earners in the Arab sector. At the high levels of education the rate of self-employed and the rate of wage-earners in the Arab sector is similar. The data in this table demonstrates that the trend among Arabs with education to become self-employed is stronger than the trend among Jews with the same education.

Table 34: Rate of Self-Employed in Jewish and Arab Sectors by Field of Occupation

\begin{tabular}{|c|c|c||}
\hline & Self-employed Arabs & Self-employed Jews \\
\hline \hline Agriculture & 0.04 & 0.07 \\
\hline Industry & 0.09 & 0.07 \\
\hline Electricity \& Water & 0.00 & 0.00 \\
\hline Construction & 0.25 & 0.12 \\
\hline Car Mechanics & 0.30 & 0.18 \\
\hline Food & 0.02 & 0.03 \\
\hline Transport & 0.09 & 0.09 \\
\hline Banking & 0.02 & 0.03 \\
\hline Real Estate & 0.11 & 0.25 \\
\hline Management & 0.00 & 0.00 \\
\hline Education & 0.01 & 0.03 \\
\hline Health & 0.02 & 0.05 \\
\hline Services & 0.05 & 0.08 \\
\hline
\end{tabular}

As can be seen in the table above, the two areas in which there is a significant difference between the Jewish and Arab sectors is car mechanics and construction. The Arabs specialize in both these areas (55\%) which both require non- 
academic tertiary education.

\section{Factors that Influence Wages (Checked Using Regression)}

In this section, we will examine two questions. The first question is what are the factors that affect the difference between self-employed income and wage-earner income. The second question is what are the factors that affect the difference between the income of self-employed Jews and the income of self-employed Arabs $^{4}$. In this case too, the sample refers only to men. Observations of people who are not working, or of people who are working both as wage-earners and as self-employed were not included in the sample. Additionally, observations were not included for workers who had an unclear level of education. In the end, the sample consisted of 9220 observations.

The dependent variable in the model is income earned by the workers (self-employed and wage-earning workers).

The independent variables are:

1. Dummy variable for self-employed worker

2. Dummy variable for self-employed Arab worker

When these two variables are used together in the regression, the coefficient of dummy variable for self-employed worker shows the difference between wage-earning worker and Jewish self-employed worker; and the coefficient of selfemployed Arab worker shows the difference between self-employed Jewish and self-employed Arab.

3. Years of education: according to the accepted hypothesis workers with more years of education will receive a higher income.

4. Dummy variable for marriage: based on previous studies, it can be assumed that the income of married men will be higher.

5. Year of birth: based on previous studies, income and age are linked in a U-shape. This variable will therefore appear twice - once linearly, and the second time to the power of $2 .{ }^{5}$ Although there is concern about a link between the marriage variable and the year of birth, the correlation coefficient between them is only -0.48 .

6. Type of diploma received from last educational institute: this item refers to the diploma received by the worker from the last educational institute in which he studied.

The possibilities are: graduation from elementary school, graduation from high school, certificate of matriculation, graduation from a non-academic tertiary educational institute, Bachelor of Arts (BA), Master of Arts (MA), Doctor of Philosophy (PhD). The type of diploma is expressed in the regression by using a sequence of dummy variables. Each institution is allocated a dummy variable. Workers for whom this institution is their last place of study will therefore receive the value "1" while all the other workers will receive a value of "0". It is known that when using a sequence of dummy variables one group must be left without a variable. In the regression of this study, the group without the variable was the workers whose last diploma received was from graduating elementary school (the lowest level of education possible).

Note that all these variables check the condition of the workers, while the purpose of this study is to check the differences between the self-employed and the wage-earners and between Arabs and Jews. Therefore, in addition to the six variables mentioned above, two more groups of variables were added to the regression:

A. Each of the variables from 3 to 6 were multiplied by a dummy variable for a self-employed worker.

B. Each of the variables from 3 to 6 were multiplied by a dummy variable for a self-employed Arab worker.

In order to understand the effect of the doubled variable, we will take the example of the education in years variable. In the regression, if the three following variables that appear (1) years of education; (2) years of education multiplied by the dummy variable for self-employed; (3) years of education multiplied by the dummy variable for Arab selfemployed; then the coefficient of years of education will show the effect of years of education on wage-earners, the second variable will show the difference between the effect of years of education on the wage-earners and their effect on Jewish self-employed, and the coefficient of the third variable will show the difference between years of education of a self-employed Jew, and the years of education of a self-employed Arab.

Analyzing these variables in a different way shows that the total of the first two coefficients (the coefficient for the number of years of education, and for the number of years of education of the Jewish self-employed) demonstrates the effect of the number of years of education on the income of self-employed Jews. Using the same method of analysis but

${ }^{4}$ The difference between the wages earned by Jewish wage-earners and wages earned by Arab wage-earners is subject matter for another study.

5 (Year of Birth ) ${ }^{2}$ 
with three coefficients (adding to the previous total the third coefficient for the years of education for Arab self-employed) shows the effect of years of education on the income of self-employed Arabs.

The same effect will be produced by multiplying each of the other variables by dummy variables. Table 35 shows the outcome of the regression. Variables with a level of significance of over $5 \%$ were omitted from the regression, and are therefore not included in the table. It can be said the variables that do not appear in the table do not affect the income.

Table 35: Factors Affecting Income (Regression Results)

\begin{tabular}{|c|c|}
\hline Variable & Coefficient \\
\hline Years of education & 634 \\
\hline Number of years of education of self-employed & -299 \\
\hline Number of years of education of Arab self-employed & -197 \\
\hline Self-employed (Dummy variable) & 4,257 \\
\hline Year of birth & 22,012 \\
\hline Year of birth to the power of 2- $(\text { Year of birth })^{2}$ & -5.6 \\
\hline Married (Dummy variable) & 1,814 \\
\hline Matriculation & 833 \\
\hline BA (Dummy variable) & 4,225 \\
\hline MA (Dummy variable) & 6,178 \\
\hline PhD (Dummy variable) & 8,173 \\
\hline Intercept & $-21,553,745$ \\
\hline Adjusted R-squared & 0.23 \\
\hline
\end{tabular}

The most interesting conclusion in terms of this study involves the effect of the number of years of education on the income of self-employed Jews in comparison to the effect on the income of self-employed Arabs. As can be seen, the coefficient for the variable "Number of years of education of self-employed" and also the coefficient for the variable "Number of years of education for self-employed Arab" are negative. These results are significant because they show that the effect of the number of years of study on the income of self-employed Arabs is smaller than the effect it has on the income of self-employed Jews ${ }^{6}$.

This result can indicate that educated Arabs find it difficult to integrate into the Israeli labor market as wage earners and therefore many Arabs with higher education are self-employed. The outcome is that many Arabs with higher education are self-employed in occupations that are not particularly high-paid. Consequently, in the Arab sector the number of years of study does not greatly influence the level of income. As shown in table 32, the tatio between the average income of the self-employed and of wage-earners in the Arab sector is 0.683 compared to 0.534 in the Jewish sector. It is probable that the fact that Arabs with higher education are self-employed rather than working as wageearners is one of the factors that contribute to this situation.

If we review the other coefficients, we will find that the coefficient for the dummy variable "Married" is positive. In other words the income of married men is greater. No difference was found in this field between self-employed and wageearners or between Arabs and Jews (dummy variables for marriage according to groups that were not significant). This is similar to the results of studies that were carried out in other parts of the world. If the effect of age is checked, it is possible to see that the coefficient Year of Birth is positive and that the coefficient of Year of Birth to the power of 2 is negative. This is significant because the link between the year of birth and income is an inverted $U$ shape (the maximum income is received at age 51). Also on this point we did not find any difference between wage-earners and self-employed or between Jews and Arabs. This result matches the results of studies carried out in other parts of the world. In the list of dummy variables for different types of diplomas, it is possible to see that as we go higher up the list of diploma type the coefficient also increases; in other words, the income increases. Also here we did not find a significant difference between wage-earners and self-employed, or between Jews and Arabs.

${ }^{6}$ Another way of viewing these results is to calculate the coefficient totals. The total of the coefficients for the first two variables ("years of study" and "years of study of self-employed") is $634-299=335$, and the total of all three variables ("years of study", "years of study of self-employed", and "years of study of self-employed Arabs") is $634-299-197=138$. In both cases, the total of the coefficients is positive, but the total that includes the coefficient for the variable "years of study of self-employed Arabs" is smaller. 


\section{Conclusion}

One of the important problems that the world must deal with today is the integration of ethnic minorities in the general labor market which is usually dominated by the ethnic group which comprises the majority in the country. One of the subjects addressed in this context is the way in which the workforce of each of these two groups is divided between wage-earners and the self-employed. In this framework the study examined whether there are differences between the minority group and the majority group in three areas: the rate of self-employment in the work force, the level of income of the self-employed compared to the wage-earners, and the level of education of the self-employed compared to that of the wage-earners. The study examined these questions against the Israeli economy where the minority group includes the Arab community while the majority group consists of the Jewish community. Although the minority group in this study does not consist of immigrants, in many ways their situation is similar to that of immigrant groups in European countries.

The results of the study indicate that the rate of self-employment in the majority and the minority groups is almost identical. However, in contrast with this finding, significant differences were found in the area of income and the effect of education. In the majority (Jewish) group the income earned by the self-employed and by wage-earners was almost the same, whereas in the Arab (minority) sector the income of the self-employed was higher. It is important to note that the income of the Jewish group is much higher in both the self-employment sector and in the wage-earners sector. It therefore seems that the relative advantage of the Arabs in the self-employed sector is derived primarily from weakness in the wage-earners sector. In another result that reinforces the conclusion regarding education it is interesting to see that the effect of education on the income of self-employed Arabs is less than the effect of education on the income of wageearning Jews. This result could indicate that educated Arabs experience difficulties integrating into the Israeli labor force as wage-earners and consequently many Arabs with higher education are self-employed. According to the conclusion that can be derived from these results, the Arab sector has a relative advantage in the self-employment sector that stems from weakness in the wage-earning sector. The government must therefore, at least in the short term, encourage the selfemployment sector of the minority group thereby enabling them to increase their income and to improve their socioeconomic situation. Studies carried out in other countries found that the main problem in this area is the lack of financial liquidity and their inability to receive credit. It is important to find ways that will enable the minority group to overcome these obstacles. In the long term, ways need to be found that will also enable minority groups to become effectively integrated into the labor market as wage-earners.

\section{References}

Andersson, P. , \& Wadensjö, E. (2004). Self-employed immigrants in Denmark and Sweden - a way to economic self-reliance?. IZA, Discussion Paper No. 1130. Retrieved from http: //papers. ssrn. com/sol3/papers. cfm?abstract_id=542822

Becker, G. S. (1993). Human Capital: A Theoretical and Empirical Analysis, with Special Reference to Education. Chicago: University of Chicago Press

Blanchflower, D. G. (2004). Self-Employment: More May Not Be Better. Swedish Economic Policy Review, 11 (2), 15-74.

Davis, S. J. , Haltiwanger, J. C. , \& Schuh, S. (1996). Job creation and destruction. Cambridge, MA: MIT Press,

Friedman, F. ,\& Zussman, N. (2008). Labor Quality in Israel. In Research Department, Bank of Israel. Retrieved from http: //www. boi. org. il/he/Pages/Default. aspx.

George, J. B. (1986). The Self-Employment Experience of Immigrants. NATIONAL NBER, Working Paper No. 1942. retrieved from http: //www. nber. org/papers/w1942. pdf.

Gharrah, R. , \& Cohen, R. (2001). Poverty Among Israeli Arabs and Sources of Inequality Between Arabs and Jews. The Economic Quarterly, 48, $485-517$.

Gindling, T. H. \& Newhouse D. (2014). Self-Employment in the Developing World. World Development, 56, 313-331.

Haberfield, Y. (1990). Salary discrimination against women in Israel: a conceptual framework, research methods, findings and trends. Human Resources and Labor Relations in Israel. Tel Aviv: Ramot.

Hasson, S. , \& Abu-Asbah, K. (2004). Jews and Arabs in Israel Facing a Changing Reality. In Floersheimer Studies. Retrieved from http: //www. fips. org. il/Site/p_publications/item_en. asp?doc=\&iss=\&iid=661.

Hasson, S. , \& Karayanni, M. (2006). Barriers to Equality: The Arabs in Israel. In Floersheimer Studies. Retrieved from http: //www. fips. org. il/Site/p_publications/item_en. asp?doc=\&iss=\&iid=768.

van Stel, A. , Sander, W. , Thurik, R. , Reynolds, P. , \& de Wit, G. (2003). Explaining nascent entrepreneurship across countries. SCALES-paper N200301, EIM Business and Policy Research. Retrieved from www. eim. nl.

Wagner, J. (2004). Nascent Entrepreneurs. IZA, Discussion Paper No. 1293. Retrieved from http: //ftp. iza. org/dp1293. pdf.

Zulema, V. (2013). Self-Employment as an Indicator of Segmented Assimilation among Six Ethnic Minority Groups. Entrepreneurship Research Journal, Manuscript 1063. Retrieved from http: //www. degruyter. com/view/j/erj. 2012. 2. issue-4/2157-5665.1063/2 157-5665. 1063. xml. 